\title{
THE NARRATOR'S VOICE OF FREEDOM IN RALPH ELLISON'S INVISIBLE MAN: A STUDY OF POSTCOLONIAL LITERATURE
}

\author{
Khotimatul Khusnah $^{1}$, Vita Vendityaningtyas ${ }^{2}$ \\ Department of English Teaching, IKIP PGRI Madiun, Indonesia \\ khotim06@gmail.com ${ }^{1}$, venditya@gmail.com ${ }^{2}$
}

\begin{abstract}
The purpose of this research is to describe the position of Black people as the folk who get discrimination in America and explain the Narrator's voice as the Black people in conveying the equality between Black and White people in America that is represented in Invisible Man novel. This research uses qualitative research. The researcher needs postcolonial literature by Lois Tyson to get evidences the effects and goals of the author in creating a story. The analysis reveals that Black people include subordinate people, oppressed minority group, and lower class that always suppressed and exploited by superior people who have power. Black people try to fight against superior to show their feeling of freedom for getting the same position and equality as White by conveying their voice through protest. The conclusion shows that inferiority makes Black people who have lower position in society get oppression that cause physical and mental disturbance from superior and the Narrator tries to struggle and get confession of Black people from the domination of White in order to survive their existence in society by conveying the voice with non-violence way through speech, action and music.
\end{abstract}

Keywords: Postcolonialism, Positioning, Subaltern, Freedom, Voice

\section{A. Introduction}

Invisible Man written by Ralph Ellison in 1952 is chosen by the researcher to be analyzed. This novel tells about Black identity which is socially ignored. Besides, this novel shows the nationalism of the main character's grandfather whose advice says "keep this Nigger-boy running" through his dream. In order to keep and get their identity, Black people struggle to show their desire for getting their freedom by using protest. The main character in this novel is called as "The Narrator", who is a Black African-American from South. He becomes increasingly alienated because of the racism he encounters. The Narrator is a gifted public speaker. In his speech, he always tries to show what he feels about the equality of race in the society. This problem makes the researcher more curious to analyze what efforts of Black will be done to overcome the problems which appear in this novel.

Dealing with this issue, the researcher will analyze a novel entitled Invisible Man by Ralph Ellison in 1952 by using Postcolonial literature by Lois Tyson in 2006. Tyson (2006: 418) writes that as a domain within literary studies, postcolonial criticism not only consists of a subject matter that literature produced by culture developed in response to colonial domination but also theoretical framework that seeks to understand the operations politically, socially, culturally and psychologically of colonialist and anticolonialist ideologies. It means 
that postcolonial is the interpretation of literature which is influenced by the experience of people about the event in the colonial domination.

Based on the explanation above, the researcher is curious about the story. The researcher wants to know the position of Black in USA because the novel would make people eager to read it. Besides, the researcher wants to know the main character's voice to get his equality as White in USA, where USA is one of the countries that respect human rights. This case is interesting to be analyzed. It will be explained more in this study. The researcher will focus on analyzing the Narrator's voice to convey his struggle to get the equality and position the same as White people.

\section{B. Method}

The researcher uses qualitative research because the research analyzes the social phenomena in the various condition of people's life including social and individual setting. In qualitative research, the researcher begins the study by getting data from the primary and secondary data (Ary et al, 2010: 443) focusing on Invisible Man novel and resources such as journal, article, or web related with the analysis of the position of Black in America as study of postcolonial literature. This research takes documentation as technique of collecting data because this research is qualitative research (Yin, 2011: 147). The researcher collects the data through reading the novel, browsing the related data, doing research, reviewing related studies to comprehend the conceptual models, and using theory of postcolonial literature to interpret the social phenomena about the position of Black people in USA represented in Invisible Man novel. This study uses content analysis because the data form of text or literary document Holsri (in Berg, 2001: 240).

\section{Result}

To begin with the primary data, the following is the portrayal of the Narrator's voice in Invisible Man novel. The distinguishing events will be several ones; the education of the Narrator, the job occupation of the Narrator, the housing of the Narrator, and the Brother community that is chosen by the Narrator as the community that fight against discrimination. It is necessary to identify the description of the Narrator's Voice in the novel to see how it is presented in the text in order to get discussion.

From the beginning of the story the Narrator is invited to the local men's club to read the speech he prepared for his high school graduation. He gives the speech and is rewarded with 2 | The Narrator's Voice of Freedom in Ralph Ellison's Invisible Man 
a briefcase and a scholarship to a Black collage, but only after he endures the humiliation of performing for the White men such as lawyers, preachers, teachers, and merchants there. He and several Black boys are forced to box with blindfolded each other while the White men laugh at their pain.

The Narrator goes off to college and determines to model himself after Dr. Bledsoe, the college's dean who is well represented in his community and his field. Unfortunately, the Narrator makes a dreadful mistake when he is driving Mr. Norton, a wealthy White man who as one of the founders and a donator a great deal of money to the college. He inadvertently says the side secret of the Black race by allowing Mr. Norton to stop and speak with Trueblood, a Black man from the Black community because he gets his own daughter pregnant. After meeting with Trueblood, Mr. Norton feels weak and the Narrator takes Mr. Norton back to campus. Dr. Bledsoe is so furious with the Narrator's stupidity that he expels him. Dr. Bledsoe is offering some hope to the Narrator by asking him to send some letters of recommendation to deliver to the school's trustee in New York. Dr. Bledsoe tells to the Narrator that if he makes enough money for tuition, he can come back to school.

The Narrator sets out for the city unaware that the letters of recommendation are really a hoax just to get him quietly away from the campus. After knowing it, he takes a job in a paint factory. He works with many White people who give unfair treatment to him such as Mr. Kimbro as supervisor in the factory. The Narrator is always commanded and mistaken by Mr. Kimbro. When he works, he gets an accident there. Finally, he turns out from factory.

After that incident, the Narrator moves into a kindly woman's apartment and stay there without a job until he gets caught up with the community called Brotherhood. Brotherhood is the community that consists of Black and White people who fight against discrimination in society. Brotherhood uses non-violence protest to convey their purpose of fighting against discrimination. The Narrator is given a position as a speaker in Harlem and he works with them. He always conveys his voice and protest of equality of race in every manner. One of the top of his protest is when Clifton, one of the members of Brotherhood is shot by White police. The Narrator makes a funeral ceremony for Clifton and invites all of Black people to join together. In the Clifton funeral, the Narrator conveys his protest to show up the injustice that got from Clifton to the world by giving speech and sing a song. 


\section{Discussion}

The discussion will start identifying the position of Black people in Ralph Ellison's Invisible Man and explaining the Narrator's voice in Ralph Ellison's Invisible Man. The necessary postcolonial data are as follows. Colonialism is reflected by something opposite each other such as upper and lower position, superior and inferior, powerful and powerless. Upper position is the place where someone or group have power and high position in the society. In other word, upper position is called colonizer in colonialism, while lower position is colonized that have no authority and power. Upper and lower position is the problem that appears in Invisible Man novel. Black people as colonized who are in the lower position, while White people are colonizer who are in the upper position. Black people get some problems in positioning themselves in education, job occupation and housing in American society.

Even though Black people have a low position in society, they still try to struggle and show their feeling of freedom to get the position and equality the same as White people by conveying their protest through speech, music, and action.

\section{A. The Position of Black People in American Society: A Social Overview \\ 1. Black People in American Education}

It is beginning from the Narrator as the Black people who gets invitation to give the speech at a gathering of the town's leading White citizens. In order to deliver his speech, he has to make a battle royal to fight with some of his schoolmate as the part of entertainment for White people. They can do what they want because they have power and authority. It can be seen from their command to fight and beat, while the Narrator and his schoolmate just follow their bad command because they do not have power to reject it. Giving bad treatment such as commanding to do something bad and torturing badly that is done by White people includes cultural colonization. According to Tyson (2006: 419) cultural colonization gives the colonized and colonizer negative behavior and lost their origin culture. It means that their origin culture which has good culture is influenced by colonization.

Even though Black people get bad treatment in order to get education, they cannot fight against it. They think that education is important for them. By getting high education, the Black people want to make their life better than before. According to Anderson (1988: 3) the goal of developing an education for Black people are to survive and extend their freedom from colonizer. In colonialism, Black people are the victim of colonization that 
English Teaching Journal, Vol. 4 No. 1, Juni 2016

ISSN: 2338-2678

their rights are seized by White people such getting good education, while White people as a dominant subject can control everything by using their power.

\section{Black People in American Occupation}

After dismissing from the college, the Narrator moves to Harlem and tries to look for a job. He gets a job at Liberty Paint which produces only white optic paint. He gets bad treatment from his supervisor, Mr.Kimbro. As the inferior, the Narrator just follows the rule even though he has difficulty to do it. It makes the Narrator as colonial subject. Colonial subject is created by colonizer to make the colonized forced to obey the colonizer as superior. According to Tyson (2006: 421) colonial subject is colonized people who obey and believe in colonizer who have superiority.

As a result, Black people get low wage because of their status, while White people get high wage in their work. It makes inequality between them. According to Western and Pettit (2005: 554) part of the decline in Black-White wage inequality appeared as a result of increased joblessness among low-skill Black men. It makes a differentiation between Black and White people in getting status in society. Consequently, inequality wage makes the effects of high discrimination policy.

\section{Black People in American Housing}

After the Narrator is discharged from his job, the Narrator is confused to get another job until he gets sick. Marry Rambo, a Black woman who lives at Harlem comes to him and helps him. The Narrator is brought by Mary to her home. She says people with same race in Harlem, they should help each other. She does not want the Narrator gets difficulty especially with White people who have power in their own country. Feeling of being not at own home can be called unhomeliness. Tyson (2006: 421) "Being "unhomed" is not the same as being homeless." It means that to be unhomed is to feel not at home even in the own home because the people who are migration feel not at home in themselves. This condition is caused by migration of Black people from rural farm or village move to America in search employment. According to Black, Muszynska, Sanders, and Tylor (2010: 3) the Great Migration is many people of African American move from South to North, Midwest, and West. 


\section{B. The Black People Positioning in American Society: The Mentality Overview}

As inferior, Black people cannot express their opinion. It is because their low position that they get. Inferior who have no power to express their different opinion called Subaltern. According to Gramsci (in Saikia, 2014: 56) "subaltern is the inferior of people in society." It means that subaltern is person or group who has lower position and gets suffering from superior in society. This position makes Black people are forced to obey the rule of White people. According to Smith (2010: 45) "the subaltern may be presented as humble, passive or ignorant, but their actual lived experience may prove the contrary." It means that subaltern is as inferior who have no power pretend to follow the superior. As a result, it disturbs the mentality of Black people.

The effects of mentalities that are got by Black people such as the attitude of anger, hatred, and impoliteness. According to Alfred (2009: 43) colonialism becomes reality in colonized people's life when their rights and freedom is seized and it causes disturbing mentalities, psychologies and behaviors of colonized people. It can be seen the Narrator's anger comes when he is blamed by Mr. Kimbro. The Narrator tries to tell that it does not his mistake but Mr. Kimbro does not care about it. As inferior, he cannot go against Mr. Kimbro even though he makes protest and complain.

\section{The Form of The Narrator's Voice in Ralph Ellison's Invisible Man}

Even though Black people have no power to fight against White people, it does not mean they do nothing. Inferior have tried to resist and show up their desire for getting freedom as they can. It is reflected in Invisible Man novel where the main character as the Narrator is Black people who try to show their desire of freedom for getting the position and equality the same as White people by giving speech and action.

\section{The Verbal Expression of The Narrator's Voice in Ralph Ellison's Invisible Man}

Giving speech is one of the soft ways that Black people choose to show up the feeling because Black people have no power. Delivering speech is not easy for Black people as inferior and subaltern who has minority group and do not have power in society. Subaltern have limited opportunities to show up their desire. According to Ashcroft et al (2007: 201) "there is no way in which oppressed or politically marginalized groups can voice their resistance, otherwise subaltern only has a dominant language or a dominant voice in which to be heard." It means that subaltern as minority 
group has no opportunity to convey their voice of resistance even though they have opinion to be heard. As the result, lack of the power of speech is the main reason why this group continues to live in obscurity although their physical presence is everywhere.

Even though subaltern have limited chance to show up their feeling, they try to deliver their speech. Mizan (2011: 83) "says the subaltern struggles and longs to be given a voice." It means that subaltern have to work hard in order to convey their desire. It can be seen that the Narrator struggles to get a chance for delivering his speech after getting bad treatment from White people.

\section{The Non Verbal Expression of The Narrator's Voice in Ralph Ellison's Invisible Man}

Using action or behavior is one of protest form that is used by Subaltern. They choose action protest because they do not have power to show up their feeling directly. Based on Saikia's statement (2014: 57) "subaltern has a voice borne along with their agony and suffering that is expressed in their attitude, manners and speech, and often bursts out in the form of rebellion." It means that to show up the desire is not only using voice but also attitude, action, and manners that represent the feeling. As inferior, using action to make protest is the effective way for Black people. The action can represent something that is in the heart and mind and it cannot be expressed directly. The protest can represent their feeling. It can be seen when the Narrator fight against White by using his action to take Black couple's things back from the street and he persuades the crowd to do it, too.

\section{The Existence of Black People During Colonialism}

Even though they obey the rule and scare to show up their desire because of their low position, they try to get their freedom for getting position and equality the same as White people by doing non-violence protest. Non-violence protest is the way to maintain their existence toward colonialism. According to Lemke and Samad's dissertation (2008: 18) the term "non-violence" itself may seem self-contradictory, as it implies a negation of violence." It means that Black people hate all of the forms of violence for making protest. It is reflected in Black people's life of the novel which as object of colonialism who survives their existence by giving non-violence protest to show up their freedom for getting position and equality the same as White people in society. Giving non-violence protest in every chance is used by Black people by such as giving speech and using music through its lyrics. 


\section{E. Conclusion}

The study of Invisible Man written by Ralph Ellison discusses about the Narrator who get social oppression by White people and their environment in United State of America. The researcher analyzes the position of Black people and the Narrator's voice phenomenon of the story as the problems of story. Discrimination makes Black people get social oppression. The effects of social oppression toward Black people are in physical and mental disturbance. Even though they get social oppression, Black people try to show their desire of freedom for getting position and equality the same as White by using non-violence ways through speech, action, and music.

\section{Acknowledgements}

The researcher would like to gratitude to the following persons: Mr. Kholil, Mrs. Mardhiyah, Muhyiddin Aziz, Yuyun Feril Apriliyanto, Ruliatul Fatimah, and her friends. Those are soul mates during the process.

\section{Bibliography}

Alfred, Gerald T. (2009). Colonialism and State Dependency. Journal de la santé autochtone. pp. $42-60$

Anderson, James D. (1988). The Education of Black in the South, 1860-1935. London: The University of North California Press.

Ary, D., Jacobs, L., Sorenson, C., and Razavieh, A. (2010). Introduction to Research in Education $8^{\text {th }}$ ed. Belmont: Wadsworth, Cengage Learning.

Ashcroft, B. (2001). On Post-Colonial Futures: Transformation of Colonial Culture. New York: Continuum.

Ashcroft, B., Griffiths, G., and Tiffin, H. (Eds). (2007). Post-Colonial Studies: Key Concept $2^{\text {nd }} e d$. New York: Routledge.

Berg, Bruce L. (2001). Qualitative Research Methods for the Social Sciences $4^{\text {th }}$ ed. Boston: Allyn and Bacon.

Black, Dan, Muszynska, M., Sanders, S., Taylor, L. (2010). The Great Migration and African-American Mortality: Evidence from Mississippi. Chicago Booth.

Bodenner, Chris. (2013). "Harlem Renaissance". Issues and Controversies in American History. pp. 1-15.

Bourassa, Alan. (2006). “Affect, History, and Race and Ellison's Invisible Man”. "CLCWeb: Comparative Literature and Culture Vol. 8, No 2, pp. 2-8. 
Femia, J. (1981). Gramsci's Political Thought: Hegemony, Consciousness, and the Revolutionary Process. Oxford: Clarendon Press.

Joseph, Peniel E. (2009). The Black Power Movement: A State of the Field. The Journal of American History. pp. 751-776.

Lamm, Kimberly. (2003). Visuality and black masculinity in Ralph Ellison's Invisible Man and Romare Bearden's photomontages. Callaloo; Arts \& Humanities. Vol.26, No.3; Full Text pp. 813-835.

Lemka, S. and Samad, A. (2008). Non-violence in the Civil Rights Movement in the United State of America. Disertation. Freie Universität Berlin JFK Institut.

Mizan, Souzana. (2011). National Geographic: Visual and Verbal Representations of Subaltern Cultures Revisited. Sao Paulo.

Neimneh, S., Muhaidat, F., Al-Omari, K., and Al-Shalabi, N. (2012). Genre, Blues, and (Mis) Education in Ralph Ellison's Invisible Man. Cross-Cultural Communication. Vol. 8, No. 2, pp. 61-72.

Saikia, Gitali. (2014). Revolutionary Artist Dr. Bhupen Hazarika: Voicing the Silence of the Subaltern. Asian Journal Humanities and Social Sciences. Vol. 2. No. 4, pp. 55-65.

Shands, Kerstin W. (2008). Neither East nor West: Postcolonial Essays On Literature, Culture, and Religion. Sweden: Sodertorns Hongskola.

Smith, Kylie. (2010). Gramski at the Margins: Subjectivity and Subalternity in a Theory of Hegemony. International Gramsci Journal No. 2, pp. 39-50.

Tylor, Q. (2000). The African American Experience: A History of Black Americans from 1619 to 1890 . Departement of History University of Washington

Tyson, L. (2006). Critical Theory Today: A User Friendly Guide. New York: Routledge.

Western, Bruce and Pettit, Becky. (2005). Black-White Wage Inequality, Employment Rates, and Incarceration. American Journal of Sociology. The University of Chicago Vo. 111, No. 2, pp. 553-578.

Yin, Robert K. (2011). Qualitative Research from Start to Finish. New York: The Guildford Press. 